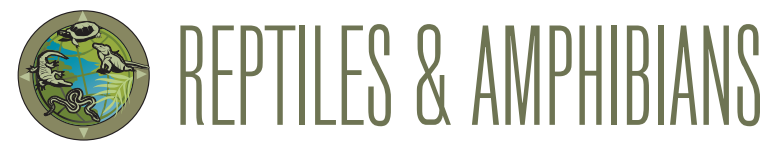

\title{
Attempted Predation of an Andaman Bronzeback (Dendrelaphis andamanensis) by an Indian Bullfrog (Hoplobatrachus tigerinus) on Havelock Island, Andaman and Nicobar Islands, India
}

\author{
Nariman Vazifdar ${ }^{1}$, Monowar Alam Khalid ${ }^{2}$, and Kaushik Lahon ${ }^{3}$ \\ ${ }^{1}$ Mumbai, Maharashtra, India (narimanvazifdar@gmail.com) \\ ${ }^{2}$ Integral University, Lucknow, Uttar Pradesh, India \\ ${ }^{3}$ Havelock, Andaman and Nicobar Islands, India
}

$\mathrm{T}$ The impact of invasive species on native species, communities, and ecosystems has been widely recognized for decades (Elton 1958; Lodge 1993a, 1993b; Simberloff 1996; Simberloff and Rejmanek 2011). The Indian Bullfrog (Hoplobatrachus tigerinus) is widely distributed in southern Asia, occurring in Nepal, Bhutan, and Myanmar through Bangladesh and India to Pakistan and Afghanistan (Frost 2021). Hoplobatrachus tigerinus has characteristics that make it a likely candidate for invasion success (Mohanty et al. 2021), and introduced populations occur in Madagascar (Glaw and Vences 2007) and possibly in the Maldives (Dutta 1997) and Laccadive Islands (Gardiner 1906). The species also was introduced recently to the Andaman and Nicobar Islands by some farmers from West Bengal, who released them into rice

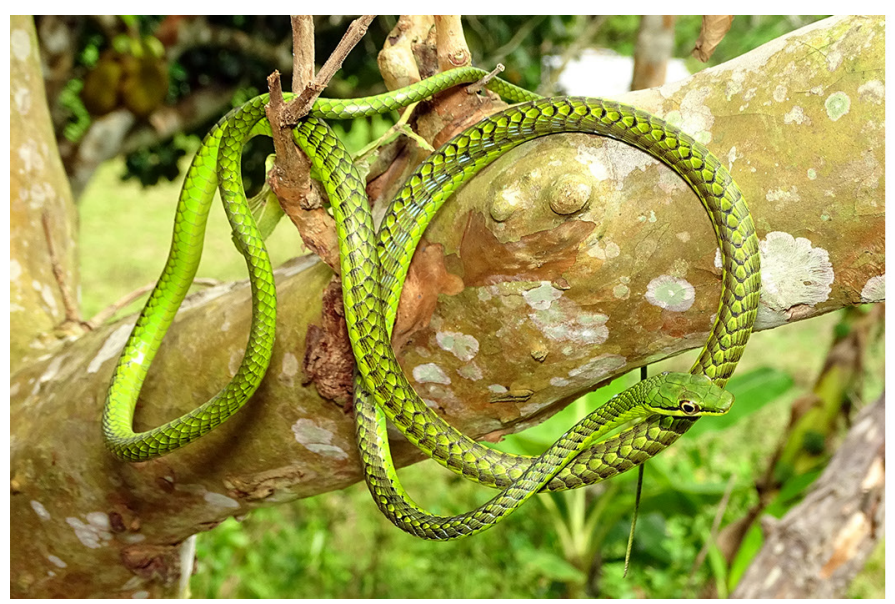

Fig 1. An Andaman Bronzeback (Dendrelaphis andamanensis) basking on a tree branch. Photograph by Nariman Vazifdar. fields in Mayabunder, Middle Andamans, from which they rapidly spread, mediated largely by humans (Harikrishnan and Vasudevan 2013; Rangaswamy et al. 2014; Mohanty and Measey 2019b). Indian Bullfrogs are known to be voracious feeders, consuming a variety of prey including small vertebrates (Padhye et al. 2008), which are represented in these islands by numerous endemic species (Das 1999), many of which are at risk of competition with or predation by Indian Bullfrogs (Mohanty and Measey 2019a).

The endemic Andaman Bronzeback (Dendrelaphis andamanensis) (Fig. 1), locally known known as Hara Shaap (= Green Snake) or Lao Lata, is diurnal and arboreal, inhabits low bushes and trees and feeds on frogs, lizards, geckos, and even birds (Whitaker and Captain 2004).

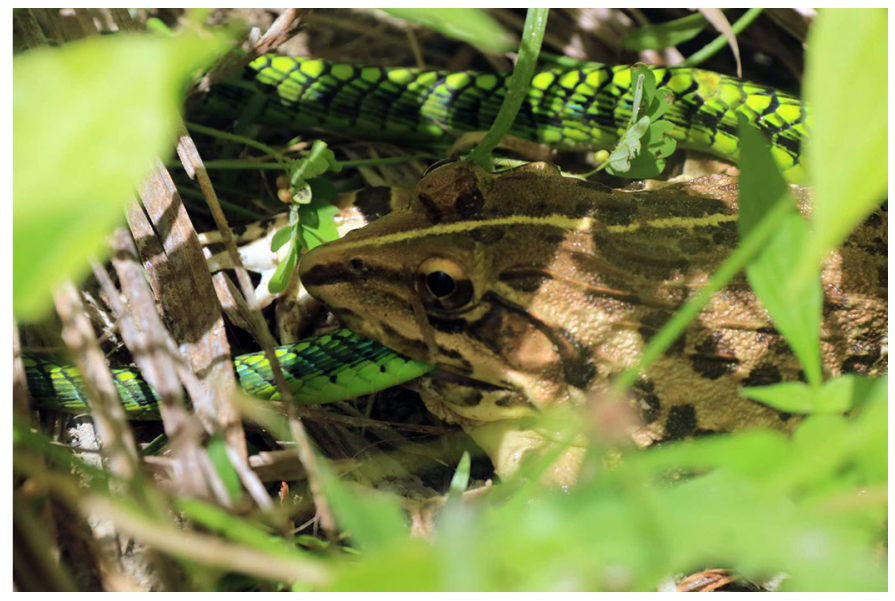

Fig 2. An Indian Bullfrog (Hoplobatrachus tigerinus) trying to eat an Andaman Bronzeback (Dendrelaphis andamanensis) on Havelock Island, Andaman and Nicobar Islands, India. Photograph by Kaushik Lahon. 
At about $1215 \mathrm{~h}$ on 7 July 2021 at the bottom of Yullatung Hill, \#5 Havelock, KL encountered an Indian Bullfrog with an Andaman Bronzeback in its mouth (Fig. 2). The frog was using its forelimbs in an effort to push more of the struggling snake's body into its mouth. After about ten minutes, the frog suddenly jumped and let go off the snake, which quickly escaped up a nearby tree. The frog then retreated into the undergrowth.

\section{Acknowledgements}

We thank the various persons who motivated us to write this note.

\section{Literature Cited}

Das, I. 1999. A noteworthy collection of mammals from Mount Harriet, Andaman Islands, India. Journal of South Asian Natural History 4: 181-185.

Dutta, S.K. 1997. Amphibians of India and Sri Lanka (Checklist and Bibliography). Odyssey Publishing House, Bhubaneswar, Orissa, India.

Elton C.S. 1958. The Ecology of Invasions by Animals and Plants. Methuen \& Co., London, UK.

Frost, D.R. 2021. Amphibian Species of the World: An Online Reference. Version 6.1. American Museum of Natural History, New York, New York, USA. https://doi.org/10.5531/db.vz.0001. <https://amphibiansoftheworld.amnh. org/index.php>.

Gardiner, J.S. 1906. Notes on the distribution of the land and marine animals, with a list of the land plants and some remarks on the coral reefs, pp. 1046-1057. In: J.S. Gardiner (ed.), The Fauna and Geography of the Maldive and Laccadive Archipelagos. Cambridge University Press, Cambridge, UK.

Glaw, F. and M. Vences. 2007. A Field Guide to the Amphibians and Reptiles of Madagascar. Vences and Glaw Verlag, Köln, Germany.
Harikrishnan, S. and K. Vasudevan. 2013. Recent introduction and spread of Indian bullfrog Hoplobatrachus tigerinus (Daudin, 1802) into the Andaman Islands. Aliens 30: 42-43.

Lodge, D.M. 1993a. Biological invasions: Lessons for ecology. Trends in Ecology and Evolution 8: 133-137. https://doi.org/10.1016/0169-5347(93)90025-K.

Lodge, D.M. 1993b. Species invasions and deletions: Community effects and responses to climate and habitat change, pp. 367-387. In: P.M. Karieva, J.G. Kingsolver, and R.B. Huey (eds.), Biotic Interactions and Global Change. Sinauer Associates, Sunderland, Massachussetts, USA.

Mohanty, N.P. and G.J. Measey. 2019a. What's for dinner? Diet and potential trophic impact of an invasive anuran Hoplobatrachus tigerinus on the Andaman Archipelago. PeerJ 6: e5698. https://doi.org/10.7717/peerj.5698.

Mohanty, N.P. and G.J. Measey. 2019b. Reconstructing biological invasions using public surveys: a new approach to retrospectively assess spatio-temporal changes in invasive spread. Biological Invasions 21: 467-480. https://doi. org/10.1007/s10530-018-1839-4.

Mohanty, N.P., A. Crottini, R.A. Garcia, and G.J. Measey. 2021. Non-native populations and global invasion potential of the Indian bullfrog Hoplobatrachus tigerinus: a synthesis for risk-analysis. Biological Invasions 23: 69-81. https:// doi.org/10.1007/s10530-020-02356-9.

Padhye, A., K. Manamendra-Arachchi, A. de Silva, S. Dutta, T. Kumar Shrestha, S. Bordoloi, T. Papenfuss, S. Anderson, S. Kuzmin, M.S. Khan, and R. Nussbaum. 2008. Hoplobatrachus tigerinus. The IUCN Red List of Threatened Species 2008: e.T58301A11760496. https://dx.doi.org/10.2305/IUCN. UK.2008.RLTS.T58301A11760496.en.

Rangasamy, V., K. Chandra, C. Raghunathan, and K. Venkataraman. 2014. Amphibians and reptiles in Andaman and Nicobar Islands: Diversity and distribution, pp. 124-130. In: Souvenir: Island Biodiversity. Uttar Pradesh State Biodiversity Board, Lucknow, Uttar Pradesh, India.

Simberloff, D. 1996. Impacts of introduced species in the United States. Consequences: Natural Implications of Environmental Change 2: 13-22.

Simberloff, D. and M. Rejmanek (eds.). 2011. Encyclopedia of Biological Invasion. University of California Press, Berkeley, California, USA.

Whitaker, R. and A. Captain. 2004. Snakes of India. The Field Guide. Draco Books, Chennai, India. 